\title{
Tracing, Value and Transactions
}

\author{
Tatiana Cutts
}

Key words: Tracing; Transactions; Value; Debts; Payments.

\section{Abstract}

Tracing is generally understood to be the process of following value through one or more substitutions, by which a claimant 'transmits' his claim from the right substituted into its exchange product. Understood thus, the exercise of tracing has been made increasingly difficult to conduct and predict by the development of complex payment mechanisms involving multiple payment instructions and interceding periods of indebtedness. This article argues that concepts of value are conceptually and practically misleading. Identifying and determining the content of transactions are normative processes that depend, not upon identifying the precise mechanisms by which a particular change in legal relations is sought and executed, but rather upon the manifested intentions of the transacting parties. This allows us to deal straightforwardly with complex payment structures, clearing and credit, and to focus instead upon the role of transactions in the justification for a resulting claim.

Dr. Tatiana Cutts

Lecturer in Law, University of Birmingham

$(+44) 1214146307$

T.Cutts@bham.ac.uk

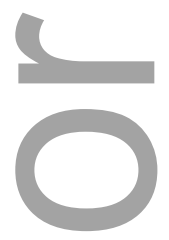

\section{Tracing, Value and Transactions}

\section{Tatiana Cutts*}

Tracing is generally understood to be the process of following value through one or more substitutions, by which a claimant 'transmits' his claim from the right substituted into its

This is the author manuscript accepted for publication and has undergone full peer review but has not been through the copyediting, typesetting, pagination and proofreading process, which may lead to differences between this version and the Version of Record. Please cite this article as doi: 10.1111/1468-2230.12189.

This article is protected by copyright. All rights reserved. 
exchange product. Understood thus, the exercise of tracing has been made increasingly difficult to conduct and predict by the development of complex payment mechanisms involving multiple payment instructions and interceding periods of indebtedness. This article argues that concepts of value are conceptually and practically misleading. Identifying and determining the content of transactions are normative processes that depend, not upon identifying the precise mechanisms by which a particular change in legal relations is sought and executed, but rather upon the manifested intentions of the transacting parties. This allows us to deal straightforwardly with complex payment structures, clearing and credit, and to focus instead upon the role of transactions in the justification for a resulting claim.

INTRODUCTION

A simple idea unites contemporary tracing theory across the common law world: when we trace we follow a continuous thread - value - from one right to another, which we do by identifying one or more 'transactional links'.1 Tracing's 'central case' is thus a straightforward one: if $\mathrm{T}$, who holds title to a $£ 10$ note on trust for $\mathrm{B}$, buys with it a bottle of wine, value moves from title to the note to title to the wine, so that any claims B had to the former are transmitted to the latter.

This insistence that there is some directness, a continuous thread that, because it is 'in the very nature of things', 2 can be established independently of intention, has

* Lecturer in Law, University of Birmingham. I am very grateful, with the usual disclaimer, to Jamie Glister, James Lee, Charles Mitchell, Duncan Sheehan, Lionel Smith, Rob Stevens and Fred Wilmot Smith for comments on earlier drafts, and to participants at the Obligations VII Conference for comments on the version presented in July 2014 at the University of Hong Kong.

1 See, eg, Kwai Hung Realty Co Ltd v Yip Fung Sheung [1997] HKEC 683; Foskett v McKeown [2001] 1 AC 102; Waxman v Waxman [2002] CarswellOnt 3047, [2002] OTC 443; Grant v St Marie 2005 CarswellAlta 71, 2005 ABQB 35, [2005] AWLD 1355; Hillig v Darkinjung Pty Ltd [2006] NSWSC 1217 Pacific Electric Wire \& Cable Co Ltd v Texan Management Ltd [2008] 4 HKLRD 349; CY Foundation Group v Cheng Chee Tock [2012] 1 HKLRD 532; Eaton v LDC Finance Limited [2012] NZHC 1105 and Wee Chiaw Sek Anna v Ng Li-Ann Genevieve [2013] SGCA 36.

2 C. Hare, 'Tracing Value and the Value of Tracing' (2013) 24 JBFLP 249, 266.

This article is protected by copyright. All rights reserved. 
however made it increasingly difficult to apply principles of tracing to modern payment mechanisms; a party who wishes to trace through multiple intermediate accounts is typically required to evidence a series of 'direct' substitutions, linking debits to credits in an unbroken chain, ${ }^{3}$ and judges have often, but not invariably, concluded that the process is automatically thwarted if money is paid into an overdrawn bank account ${ }^{4}$ or clearing system..$^{5}$ The exercise is thus inextricably bound up with the particular manner in which a payment is executed, a variable that is almost always entirely outwith the claimant's control.

In this article I argue that the idea of 'tracing value' is both conceptually and practically misleading. The content of a transaction cannot be determined without reference to the intention of the parties, deduced from the agreement as a whole. If this process reveals that the parties intended several steps to work together, the transaction is to be characterised accordingly. This allows us to ignore the interposition of intermediate payment instructions, clearing and credit, and to focus instead on the role of transactions in the claims that result from their proof.

The purpose of this article is not, therefore, to provide a positive account for which our monolithic law of tracing can simply be substituted, but rather to demonstrate that those problems which have occupied centre stage in tracing discourse are illusory, and to direct attention instead to the issues that arise once value metaphors are removed. In so doing, it becomes manifest that there are important differences

${ }^{3}$ Relfo v Varsani [2014] EWCA Civ 360.

${ }^{4}$ Conlan v Connolly [2011] WASC 160; CY Foundation Group v Cheng Chee Tock n 1 above; Rea v Russell [2012] NZCA 536.

${ }^{5}$ Agip (Africa) Ltd v Jackson [1991] Ch 547; El Ajou v Dollar Land Holdings [1993] 3 All ER 717; Nimmo v Westpac Banking Corp [1993] 3 NZLR 218; Bank Tejarat v Hong Kong and Shanghai Banking Corp (CI) Ltd [1995] 1 Lloyds Rep 239; Citadel General Assurance Co v Lloyds Bank Canada [1997] 3 SCR 805; Equiticorp Industries Group Ltd v The Crown (No 47) [1998] 2 NZLR 481; Bank of America v Arnell [1999] Lloyds Rep Bank 399; London Allied Holdings v Lee [2007] EWHC 2061; BMP Global Distribution Inc v Bank of Nova Scotia [2009] 1 SCR 504.

This article is protected by copyright. All rights reserved. 
between the various fact-patterns currently described by reference to principles of tracing. Rather than attempting to follow the path of value from one asset to another, we are instead faced with the task of determining the normative role of a transaction entered into by an agent without the consent of his principal; ${ }^{6}$ a transaction entered into by a trustee or other fiduciary without the capacity to change the claimant's position with respect to some third party; ${ }^{7}$ a transaction executed by a non-fiduciary wrongdoer 8 and a transaction entered into by an innocent party, with whom the claimant had no prior relationship. ${ }^{9}$ The purpose of this article is to equip us to see and start that task.

\section{TRACING}

The kind of fact pattern that typically frames an academic analysis of tracing is as follows:

Example (i): T holds title to a $£ 10$ note on trust for B. T uses that note to purchase a bottle of wine. He does not have B's authority to do so.

In such a case B is said to be able to follow the path of value from T's title to the note to T's title to the bottle of wine, and, accordingly, may assert a claim the latter. In the leading text on the subject Smith explains:

Consider the simplest case in which the plaintiff's asset is exchanged by the defendant for some other asset, and the plaintiff wants to trace into the new asset. The only connection which the plaintiff has to the new asset is that it was acquired with the old asset. The defendant acquired the value inherent in the new asset with the value

${ }^{6}$ eg, Relfo v Varsani [2014] EWCA Civ 360.
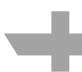

7 eg, Taylor v Plumer (1816) 3 M \& S 562, 105 ER 721; Foskett v McKeown [2001] 1 AC 102; Independent Trustee Services v GP Noble Trustees [2012] EWCA Civ 195.

8 eg, Banque Belge pour l'Etranger v Hambrouck [1921] 1 KB 321; Shalson v Russo [2005] Ch 281.

${ }^{9}$ eg, Jones v Trustee of FC Jones \& Sons [1997] Ch 159.

This article is protected by copyright. All rights reserved. 
inherent in the old asset. That is why we say we trace value: it is the only constant that exists before, through and after the substitutions through which we trace. It exists in a different form after the substitution, and that is what can justify a claim to the new asset. 10

Adopting in its entirety the logic of value transfers, courts have preserved a 'tight focus on asset exchanges',11 insisting upon the identification of a chain of substitutions through which a continuous flow of value can be pursued. ${ }^{12}$

However, few of our tracing cases - almost all of which involve bank transfers are encapsulated as readily as Example (i) by the terminology of asset exchanges:

Example (ii): T holds a bank account on trust for B. He transfers $£ 1000$ from the trust account to C's account.

In Relfo v Varsani Arden LJ considered that,

when funds are transmitted through the banking system, what matters is that there has been an exchange of the value of the claimant's property into the next product for which it is substituted and so on down the chain of substitutions. ${ }^{13}$

'Exchange ... into' is revealing. In Example (ii) B cannot follow the original trust right: when a bank transfer is made the transferee does not acquire the right that the transferor gave up. ${ }^{14}$ There is nothing to follow but a 'stream of electrons'.15 But nor is

${ }^{10}$ L. D. Smith, The Law of Tracing (Oxford: OUP, 1997) 119.

11 C. Mitchell, P. Mitchell and S. Watterson (eds), Goff \& Jones: The Law of Unjust Enrichment (London: Sweet \& Maxwell, 8th ed, 2010) 1176.

12 OJSC OHL Co Yugraneft v Abramovich [2008] EWHC 2613.

${ }^{13}$ Relfo v Varsani n 3 above at [60].

${ }^{14} R$ v Preddy [1996] AC 815, 841; Robb Evans of Robb Evans \& Associates v European Bank Limited [2004] NSWCA 82 at [138].

${ }^{15}$ Agip (Africa) Ltd v Jackson n 5 above, 286.

This article is protected by copyright. All rights reserved. 
there any 'exchange', if that term is understood narrowly to refer to the process of a single actor giving up one right in return for another: at most, the changes in B and C's positions that result from the payment instruction occur as part of the same legal event. The process of following the path of value through bank transfers is thus more naturally and more often described as a process of identifying one or more 'transactional links':

In order to be able successfully to trace property it is necessary for the claimant, firstly, to identify property of his, which has been unlawfully taken from him ('a proprietary base'); secondly, that that property has been used to acquire some other new identifiable property. The new property may then have been used to acquire another identifiable asset ('a series of transactional links'). Thirdly the chain of substitutes must be unbroken. ${ }^{16}$

So, in order to trace it is thought that a claimant may either demonstrate that some right held by or for him can be linked transactionally with the right into which he seeks to trace, or he can point to a series of such links, forming an uninterrupted chain: ${ }^{17}$

Example (iii): A transfers $£ 1000$ to C’s account, from which C pays B $£ 1000$.

Here, A traces by linking his account with C's account, and C's account with B's. It is considered crucial that it is the precise account into which the sum traced is paid that is employed in the subsequent transfer. The facts of the following example are, for example, thought to be incapable of supporting an attempt to trace from A's account to C's:

Example (iv): A transfers $£ 1000$ to C's account. As a result, C pays B $£ 1000$ from a different account.

The Court of Appeal has recently reiterated the view that it is not enough for $A$ to demonstrate that $A$ and $C$ anticipated that C's payment to B would be made as a result of

\footnotetext{
16 OJSC OIL Co Yugraneft v Abramovich [2008] EWHC 2613 (Comm) at [349].

17 ibid.
} 
A's payment to $C$, if as a matter of fact the provenance of the former was an account different from that credited as a result of A's payment instruction. ${ }^{18}$

Yet, the growing complexity of modern payment mechanisms has rendered the burden of proving an unbroken chain of the kind depicted by Example (iii) increasingly onerous for a claimant to discharge, not least because a fraudulent fiduciary is unlikely to be forthcoming in their evidence as to the path of misdirected funds. ${ }^{19}$ On occasion, therefore, judges have cited 'considerations of justice and practicality' in departing from received orthodoxy to produce a result less jarring to lay perceptions of right and wrong. ${ }^{20}$ The effect is to produce a climate in which the content of the pertinent principles, and the effect of their application to the facts of a particular case, are exceedingly difficult to predict. The purpose of this section is to exemplify some of the problems that arise in attempting to trace from one right to another, and to give a brief description of the framework created by existing judicial and academic solutions.

\section{Multiple accounts}

A fraudster will invariably seek to obfuscate the path of funds misappropriated, so that few claimants in the decided cases have been able to document the precise steps by which payment from the account originally debited was effected. Giving judgment for the Privy Council in Brazil v Durant, Lord Toulson recently acknowledged that the process of establishing the requisite link between funds misappropriated and the acquisition of some new asset is likely to 'depend on inference from the proved facts'.21 Yet, despite the relative ubiquity of cases in which that inference is drawn, we have neither a clear exposition of the factors relevant to it, nor one of any hierarchy between them.
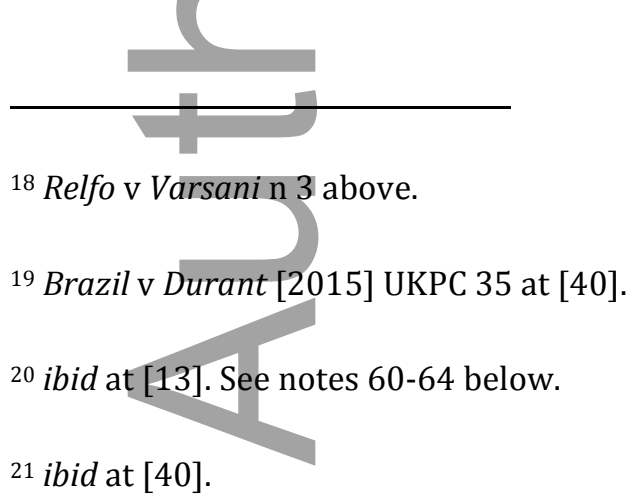
In El-Ajou v Dollar Land Holdings the claimant was one of many victims of a major share fraud carried out in Amsterdam by three Canadians between 1984 and 1985. ${ }^{22}$ It had substantial funds and securities deposited with the First National Bank of Chicago in Geneva which were under the control of an investment manager. The manager misappropriated those funds, investing them in shares traded by two Dutch companies. Each time a sum was received by those companies, a corresponding amount was deducted from that account and credited to two accounts in Geneva. The fraudsters created three Panamanian companies in order to receive their individual shares in the profits. Those funds were then transferred into three more Panamanian companies, and then again into accounts in London, after which they were invested in a joint venture to carry out a property development project in Battersea in conjunction with the first defendant, Dollar Land Holdings plc (DLH). DLH argued that the claimant had not established that the money in the Geneva account, used to secure an advance to finance the project, represented the proceeds of the fraud remitted from Gibraltar to Panama.

At first instance Millett J held that although the claimant was 'unable by direct evidence' to demonstrate that the money received into the Geneva account represented money sent to Panama, the evidence that had been adduced was 'sufficient, though only just, to enable the inference to be drawn'. ${ }^{23}$ One of the two sums received into the Geneva account was almost exactly the same as that sent from the Gibraltar account to the Panama account, and there was no evidence that the fraudsters had any significant sum available to them that did not represent proceeds of the fraud. In the judge's words, 'It is not much, but it is something; and there is nothing in the opposite scale'. ${ }^{24}$

Two decades after that decision, little advance has been made towards an articulation of circumstances relevant to the determination of such an inference. Considering the nature of the tracing exercise in a case involving multiple accounts, the

${ }^{22}$ El Ajou v Dollar Land Holdings $\mathrm{n} 5$ above.

23 ibid, 713 per Millett J.

24 ibid.

This article is protected by copyright. All rights reserved. 
Court of Appeal has recently concluded that each case is to be decided by reference to an open-ended list of factors, absent, it would appear, any shared logic.

Relfo v Varsani concerned a claim brought by the liquidator of Relfo Ltd (Relfo) against Mr Varsani to recover $\$ 878,479.35$ that had been misappropriated by its former director, Mr Gorecia. ${ }^{25} \mathrm{Mr}$ Gorecia, in breach of fiduciary duty, caused Relfo to pay $\$ 890,050$ to a company called Mirren Ltd (Mirren). The next day, another company, Intertrade Group LLC (Intertrade), paid \$878,479.35 to Mr Varsani's bank account. Despite the fact that the court had 'insufficient evidence to be able to map each step in the process'-in particular Relfo could not point to specific transactions passing between the Mirren and Intertrade accounts to show how the Relfo/Mirren payment was translated into the Intertrade payment which went to Varsani's account - Sales J held, at first instance, that the payments were so closely linked in time and amount that:

[I]t is a fair inference that the Intertrade payment was the product of a series of transactions between a number of entities and across a number of bank accounts designed to produce the result that funds paid in the Relfo/Mirren payment were (subject to the $1.3 \%$ deduction) paid on to Bhimji Varsani. ${ }^{26}$

Although it seems manifest that the judge's inference was guided by the intention of the transacting parties, on appeal Varsani argued that this approach was incorrect: irrespective of evidence as to the parties' intention, '[i]t must still be shown by evidence or inference that there is a direct chain of substitutions whereby the claimant's property was exchanged for another asset'. ${ }^{27}$

Adopting a similar position, Arden LJ concluded that the decision at first instance could only be explained on the basis that intention was not a 'major part of the evidence

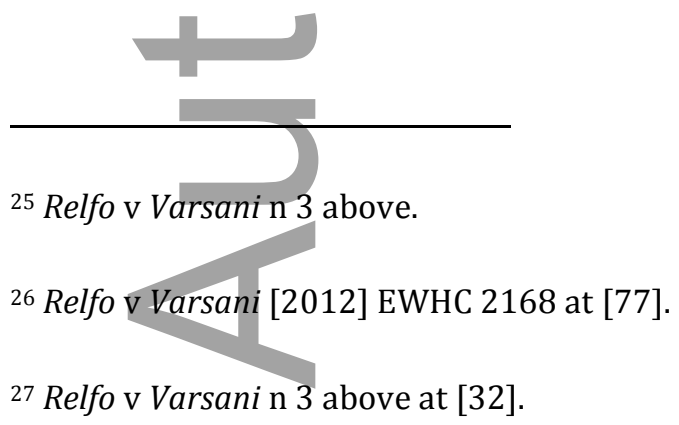


on which the judge based his inference'.28 Instead, in any case involving multiple payments, 'what matters is that there has been an exchange of the value of the claimant's property into the next product for which it is substituted and so on down the chain of substitutions. ${ }^{29}$ Her Ladyship concluded that in the instant case the chain of substitutions could be established by reference to a 'basket of factors', including, inter alia, prior dealings between the parties; access to potential money-laundering vehicles; the amount and timing of payments; and the lack of any satisfactory account of the transactions from the relevant witnesses. ${ }^{30}$

Yet, if it is not to establish the presence of a scheme designed to bring about a debit to one account and credit to another, it is not clear why such factors should be

relevant, ${ }^{31}$ and what other factors might, in a different case, enable the inference to be drawn. It is, therefore, difficult to predict the outcome of the tracing exercise in any case involving a network of payments, even where such payments are manifestly linked by some overall design.

\section{a) Clearing}

In England and Wales the rigidity of the orthodox approach to tracing has preserved an ambivalence in the application of so-called 'common law' and 'equitable' principles of tracing to the context of clearing; for so long as that duality persists, the former, but not the latter, is thought to be confounded by inter-bank payment instructions.

Agip v Jackson concerned a payment order that had been fraudulently altered to name Baker Oil as beneficiary. That order was executed by the claimant's bank, Banque du Sud, which debited their account with $\$ 518,822.92$ and instructed Baker Oil's bank

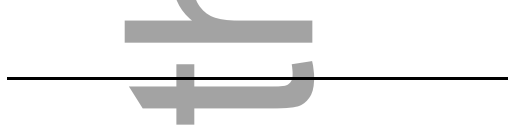
28 ibid at [58].
${ }^{29}$ ibid at [60].
30 ibid at [58].
31 This is discussed further below, in the text accompanying notes 94-106.

This article is protected by copyright. All rights reserved. 
(Lloyds Bank) to credit Baker Oil's account in London with the same sum, giving instructions to its correspondent bank in New York to reimburse Lloyds Bank. Lloyds Bank acted on those instructions. At the third defendant's behest, it then transferred the sum to the account of the defendants' firm with the bank.

Millett J held that the claimants were unable to trace at common law for two reasons, one of which was that the source of the payment could not be identified without going through the New York clearing system, 'where it must have been mixed with other money'.32

References to mixtures in the context of clearing are confusing. A 'mixed fund' ordinarily refers to a right that can be attributed to several sources. ${ }^{33}$ In Relfo v Varsani the judge at first instance held that tracing at common law was not possible where the intermediate accounts were not ring-fenced, ${ }^{34}$ the inevitability of multiple debits and credits precluding any possibility of demonstrating that the account at each stage was in whole or part the product of a right representing the misappropriated funds.

Clearing does not create this kind of problem, but rather one of identifying the chain of payment instructions by which a debit and credit are linked, and a payment thereby executed. Importantly, settlement and clearing are not identical: clearing is the process of exchanging payment orders between participating banks, ${ }^{35}$ whilst settlement is payment between the banks in settlement of their obligations inter se. ${ }^{36}$

Take the following example:

\footnotetext{
${ }^{32}$ Agip (Africa) Ltd v Jackson n 5 above, 286.

${ }^{33}$ Foskett v McKeown n 1 above.

${ }^{34}$ Relfo v Varsani n 26 above at [75] per Sales J.

35 P. Ellinger, E. Lomnicka and C. Hare, Ellinger's Modern Banking Law (Oxford: OUP, 5th ed, 2011) 562

36 ibid. See also Hare, n 2 above, 257.
} 
Example (v): A instructs Bank A to pay B, which Bank A does by instructing Bank B to credit B’s account.

In Smith's words, tracing through the steps of payment,

does not require that when Bank A paid $£ 400$ to Bank B it was the same $£ 400$ A paid to Bank A, or even that it was its traceable proceeds. It would not matter if Bank A settled with Bank B by giving it $£ 400$ worth of kiwi fruit'. ${ }^{37}$

The rights of the banks inter se are not the focus of the tracing exercise. Rather, the problem that clearing supposedly creates for the idea that we are tracing value through a series of exchanges is the necessity of identifying the precise series of payment orders that link A's right to B's: if Bank A incurs a liability to Bank B in order that B should acquire a claim against Bank B, the orthodox approach to the tracing exercise is to connect A's account to B's by identifying a continuous chain of valuable assets (A's claim against Bank A; Bank B’s claim against Bank A; B’s claim against Bank B).

A pragmatic approach to bank payments has permitted instances of clearing to be dealt with more straightforwardly by the Hong Kong courts. In Kwai Hung Realty Co Ltd v Yip Fung Sheung the defendants sought to argue that it was impossible to connect two rights once the facts involved any kind of clearing - of a cheque or electronic payment. ${ }^{38}$ The judge in the Hong Kong High Court addressed this with the words: 'The point is after all a simple one, namely whether the money received by Wing Lung under each cheque of the plaintiff is the money from the plaintiff and of the plaintiff. Any layman would have no hesitation in saying yes'. ${ }^{39}$

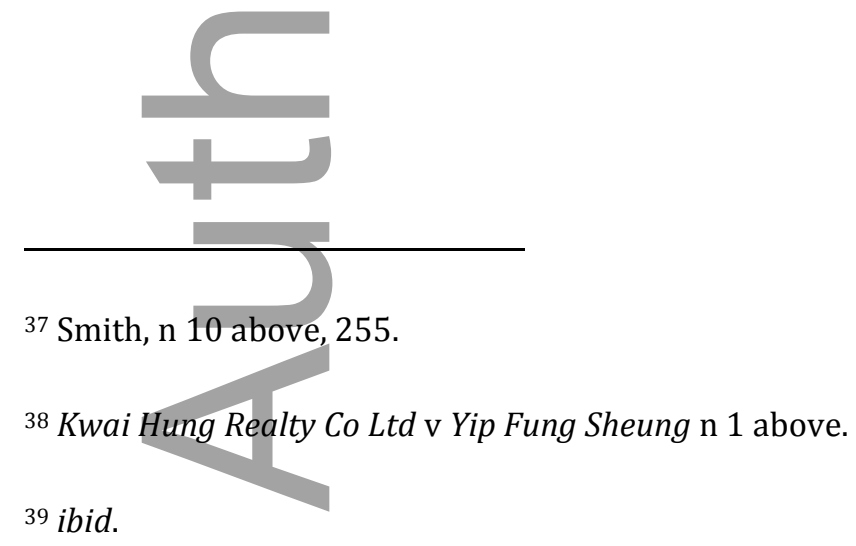

This article is protected by copyright. All rights reserved. 
Yet, Millett J's views on the clearing of electronic payments have been approved in several cases in the UK, ${ }^{40}$ Canada, ${ }^{41}$ Singapore, ${ }^{42}$ and New Zealand. ${ }^{43}$ This creates doubt about the ability of claimants to trace in cases involving other common payments mechanisms that use some form of clearing, such as debit and credit cards. ${ }^{4}$

b) Credit

The interposition of a period of indebtedness poses the most obvious problem for a claimant seeking to establish a continuous chain of valuable assets. Various judicial and academic approaches have been taken to the reconciliation of tracing principles with debt, and courts have demonstrated neither nuance nor consistency in explaining the effects of different manifestations of credit in payment.

In order to understand the lack of consensus in approaches to debt, it is first important to distinguish: (i) problems of claiming from (ii) problems that might exist in establishing a continuous chain of valuable assets, and each of (i) and (ii) from (iii) problems that might exist in the process of demonstrating a transactional link.

In the following example, although B can point to the transactional product of the original trust right, a claim to that right is valueless:

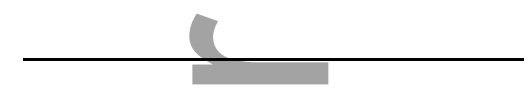

40 El Ajou v Dollar Land Holdings n 5 above, 712; Bank Tejarat v Hong Kong and Shanghai Banking Corp (CI) Ltd n 5 above, 245; Bank of America v Arnell [1999] Lloyd's Rep Bank 399, 405; London Allied Holdings v Lee n 5 above at [89], [256].

${ }^{41}$ Citadel General Assurance Co v Lloyds Bank Canada n 5 above at [57]; BMP Global Distribution Inc v Bank of Nova Scotia 4 above at [78]

42 Sumitomo Bank Ltd v Thahir Kartika Ratna [1992] 3 SLR 638 at [186].

43 Nimmo v Westpac Banking Corp n 5 above 238; Equiticorp Industries Group Ltd v The Crown (No 47) n 5 above, 698-699.

${ }^{44}$ Hare, n 2 above, 256.

This article is protected by copyright. All rights reserved. 
Example (vi): $\mathrm{T}$ holds title to a $£ 10$ note on trust for $\mathrm{B} . \mathrm{T}$ uses that note to purchase a bottle of wine. He drinks the wine.

The practical importance of this problem is clear: in Re Registered Securities Ltd, Somers J considered that 'as a matter of logic it seems evident that where a claimant's money is paid into an overdrawn account there is no fund or property to which resort can be had.' 45

A different problem is created by the indebtedness of an intermediate transacting party:

Example (vii): A transfers $£ 1000$ from his account to C's account, which is overdrawn. $C$ uses that account to transfer $£ 1000$ to B's account.

In Re Registered Securities Ltd, Somers J continued:

Nor does the position seem different when the account is further overdrawn and the additional sum is expended on some identifiable property. In such a case it is not possible to show that the claimant's money contributed to the new purchase. ${ }^{46}$

Here the problem is thought to lie, not in the absence of a valuable asset to claim, nor even in the process of demonstrating that a chain of transactions connects the relevant accounts, but rather in demonstrating that a continuous chain of value can be pursued to B's account: the intermediate account appears to be a liability, not an asset. ${ }^{47}$

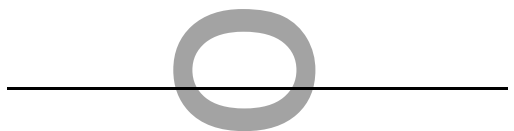

45 Re Registered Securities Ltd [1991] 1 NZLR 545, 554. It is not strictly accurate to suggest that an overdrawn account cannot constitute 'property' in the sense of 'right that can be claimed': even an overdrawn account - understood as a right to demand payment and for so long as its limit is not yet reached - remains an asset to which it is possible for another person to assert a claim. Whether such a claim is worth asserting depends upon the value of the asset that the claimant is able to reduce into his control.

46 ibid.

47 See, eg, M. Conaglen, 'Difficulties with Tracing Backwards' (2011) 127 LQR 432, 448.

This article is protected by copyright. All rights reserved. 
The last type of problem goes directly to the proof of the requisite link between assets. We know that if the asset that can be linked transactionally with a right previously held by or for the claimant is valueless, the claimant cannot transmit their claim to some other asset in the hands of the defendant with which he cannot demonstrate a transactional link. ${ }^{48}$ In the following example, therefore, B cannot assert a claim to title to the bottle of Cristal:

Example (viii): $\mathrm{T}$ holds title to a $£ 10$ note on trust for $\mathrm{B}$. $\mathrm{T}$ uses that note to purchase a bottle of wine. He drinks the wine. X gives T a bottle of Cristal.

Many cases are, however, considerably less straightforward. The fact pattern that has provoked most discussion of credit in tracing is the repayment of a debt with funds that can be linked transactionally to the claimant. This is typically expressed as 'tracing into the payment of debt',49 or 'backward tracing',50 and the particular problem that it presents is as follows: if a buyer buys an asset on credit and pays for it with the claimant's money, the seller passes title in return for the promise to pay, and releases the debt in return for payment. ${ }^{51}$ It seems, therefore, that in the following example there is no continuous chain of valuable assets:

Example (ix): B buys a bicycle from $\mathrm{C}$ for $£ 10$ on credit. A subsequently gives $\mathrm{B}$ $£ 10$, which B uses to meet the debt.

Here, however we look at it, A's rights have been substituted for the release of an obligation, and there is no immediate product of that release. The product of the substitution of A's rights is in C's hands: C exchanged title to the bicycle for a right to $£ 10$, and then the right to $£ 10$ for $£ 10$.

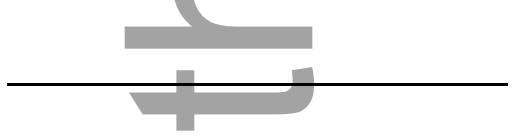

48 Director of the Serious Fraud Office v Lexi Holdings plc [2008] EWCA Crim 1443, [2009] QBD 376.

${ }^{49}$ L. Smith, 'Tracing into the Payment of a Debt' (1995) 54 CLJ 290.

50 Bishopsgate Investment Management Ltd v Homan [1995] Ch 211, 216.

51 Conaglen, $\mathrm{n} 47$ above, 450. 
Some courts have pursued this logic to its conclusion without hesitation. In Moffatt v Crawford Heiner used proceeds of trust funds to pay for title to a piano previously bought on credit. ${ }^{2}$ He gave the piano to his wife, and she later gave it to her daughter. Lukin J held that title passed on delivery of the piano to Heiner and that the trust funds could not be traced in any case involving payment by credit. ${ }^{53}$ That decision was affirmed on appeal. ${ }^{4}$

Other courts have, however, insisted on a case-sensitive approach to backward tracing. In Relfo v Varsani, even though the Intertrade payment was in fact made prior to the Mirren payment, Arden LJ considered that: 'in order to trace money into substitutes it is not necessary that the payments should occur in any particular order, let alone chronological order.'55 Her Ladyship continued: 'What the court has to do is establish whether the likelihood is that monies could have been paid at any relevant point in the chain in exchange for such a promise.'56

Arden LJ must be correct in her assertion that the problem is not strictly one of chronology. Otherwise, if participants to an inter-bank payment happen to credit the beneficiary's account prior to making the relevant debit, tracing - legal or equitable would inevitably be thwarted, a conclusion that is not borne out by the decided cases. ${ }^{57}$ But precisely what her Ladyship intended to be understood by the latter statement is not clear. The crux of the matter appears to be the determination of whether the parties anticipate that the mechanism by which a particular payment, sale or other transaction is to be executed is by two or more steps, involving the exchange of an asset for the

${ }^{52}$ Moffatt v Crawford [1924] St R Qd 241.

53 ibid, 245-246.

54 ibid, 248 (McCawley C)).

${ }^{55}$ Relfo v Varsani n 3 above at [63].

56 ibid.

${ }^{57}$ eg, Agip (Africa) Ltd v Jackson [1991] Ch 547.

This article is protected by copyright. All rights reserved. 
acquisition of an obligation to pay, and the release of that obligation for payment. But precisely whose intention is relevant, ${ }^{58}$ and which way such proof cuts, ${ }^{59}$ are questions that have not yet found satisfactory resolution.

In Brazil v Durant the claimants sought to trace the proceeds of a wide-scale fraud carried out in the late 1990s in connection with a major public works contract in Sao Paulo, Brazil.60 In order to do so they had to show that money paid into an account in the name 'Chanani' at Safra International Bank in New York could be connected with an account in the name of Durant at Deutsche Bank, Jersey. One of the issues the Jersey Court of Appeal had to consider was the status of two payments made into the Chanani account after the last of the payments out of it.

After considering the authorities, the court concluded that they did not lead to 'binary answers', so that the Jersey courts 'should not feel constrained either to adopt or reject any particular rules'.61 James McNeill QC said:

[I]n a case such as this where an asset is acquired by making a transfer out of an account before trust money is paid into the account, the true question is whether the plaintiff can establish a sufficient link between the trust money of which he was originally deprived, and the asset which has now been acquired. ${ }^{62}$

On the facts, that link was held to be manifest.

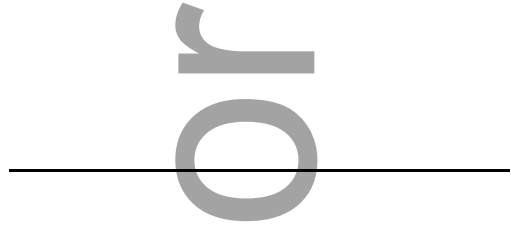

${ }^{58}$ In Relfo v Varsani n 3 above at [63], Arden LJ identified the recipient's intention as key, by contrast with the approach taken by Dillon LJ in Bishopsgate Investment Management Ltd v Homan [1995] Ch 211, 216.

${ }^{59}$ For Conaglen, $\mathrm{n} 47$ above, it proves the absence of a transaction; for Smith, $\mathrm{n} 49$ above, it proves that there is a single transaction involving delayed payment.

${ }^{60}$ Brazil v Durant $\mathrm{n} 19$ above.

${ }^{61}$ Brazil v Durant [2013] JCA 071 at [62].

62 ibid.

This article is protected by copyright. All rights reserved. 
On appeal to the Privy Council, Lord Toulson rejected the claim that the interposition of a period of indebtedness of the kind exemplified by Examples (vii) or (ix) inevitably thwarted the tracing exercise, concluding that in any such case the claimant may still be able to

establish a coordination between the depletion of the trust fund and the acquisition of the asset which is the subject of the tracing claim, looking at the whole transaction, such as to warrant the court attributing the value of the interest acquired to the misuse of the trust fund. 63

So, all that can be said with confidence is that a period of indebtedness may, but depending upon the facts and, perhaps, the jurisdiction and level of the court - will not necessarily, cause the claimant to fail to establish a link between some right of which he has been deprived and another acquired by the defendant.

Since very few payments will involve neither clearing nor credit, and most fraudsters will attempt to conceal the path of funds by some transactional contortion, the absence of a set of guiding principles is no small problem for clarity and consistency in this area of private law. In what remains of this article I argue that in order to provide a formula that is conceptually and practically robust, it is necessary to discard the conceptual premise of tracing, that there is a way in which we can meaningfully follow the path of value from one asset to another.

\section{VALUE}

Although there is now a large body of material across the common law world applying and analysing the principles discussed above, there is remarkably little close consideration of the question of what 'value', in tracing, means. Let us return to Example (i):

$\mathrm{T}$ holds title to a $£ 10$ note on trust for $\mathrm{B}$. T uses that note to purchase a bottle of wine. He does not have B's authority to do so.

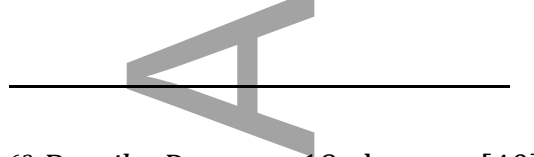

${ }^{63}$ Brazil v Durant $\mathrm{n} 19$ above at [40]. 
Recall that the way in which this is ordinarily conceptualised is as follows: B follows the path of value from title to the note into title to the wine, which allows him to transmit his claim to the former to the latter. The questions considered here are: (i) what do we mean when we say that value moves and can be located in the exchange product of some substituted right; and (ii) is this a helpful way of expressing the relationship between two rights or two transacting parties, in order to provide the foundation for some personal or proprietary claim in respect of an asset not formerly held by or for the claimant?

c) Exchange value

In law, the term 'value' most often labels a quantitative representation of the relationship between two or more commodities, calibrated by a scale expressed in monetary units. This is termed 'market value' or 'exchange value', and it allows us to express predictions about the composite effect of supply and demand in a particular market at a particular time. We often, therefore, distinguish 'exchange value' (a prediction about the price a commodity will fetch) ${ }^{64}$ from 'realising the exchange value' (the price that it does in fact fetch).

This brings us to the first sense in which we might say that value 'moves' and can be traced through a transaction: if $\mathrm{T}$ holds title to a $£ 10$ note on trust for $\mathrm{B}$ and buys with that note a bottle of wine, the exchange value of title to the note is somehow represented by the current exchange value of title to the wine - whatever that may be so that B can trace and claim the latter.

Yet, quite how this works, and what exactly we mean by the statement that value 'moves' from one to the other, is not clear. To take an extreme example, in 2006, in a story worthy of the Japanese legend of the 'Straw Millionaire', a 26 year old Canadian ${ }^{64}$ See, eg, the discussion of value in Benedetti v Sawiris [2013] UKSC 50, [2013] 3 WLR 351 at [12]-[34]
per Lord Clarke and [96]-[123] per Lord Reed. Where a quantum meruit for services rendered is
concerned, the only possible value is the predicted value of an equivalent service; the actual (realised)
value is nothing.

This article is protected by copyright. All rights reserved. 
man, Kyle MacDonald, traded a paperclip, through a series of 14 trades, for a two-story farmhouse in Kipling, Saskatchewan. ${ }^{65}$ The cases are clear that the vast divergence in the respective values of titles to the paperclip and farmhouse is no impediment to tracing from one to the other.

In Jones v FC Jones, Mr Jones made a series of unauthorised transfers from his firm's account to his wife. ${ }^{66}$ She multiplied that money fivefold by speculating in potato futures, before transferring it to a deposit account with R. Raphael \& Sons Plc (Raphaels). The Court of Appeal unanimously upheld the trustee in bankruptcy's proprietary claim to those (far more valuable) rights against Raphaels, concluding:

There is now ample authority for the proposition that a person who can trace his property into its product, provided the product is identifiable as the product of his property, may lay legal claim to that property. ${ }^{67}$

In Foskett v McKeown a trustee had misappropriated trust funds, using them to pay two out of five premiums of a life insurance policy, before committing suicide. ${ }^{68}$ The beneficiaries of the trust were held entitled to claim two fifths of the insurance payout, even though the share of the proceeds recovered by the beneficiaries far exceeded that of the contributing trust funds.

The substitute right might equally be worth less than the substituted right. If, in Example (i), the bottle of wine is worth $£ 1$, B can still identify it as the product of the original trust right, and can claim it. In Smith's words, 'there are good and bad bargains, and the invocation of 'value' as the object of the verb 'to trace' does not entail that an

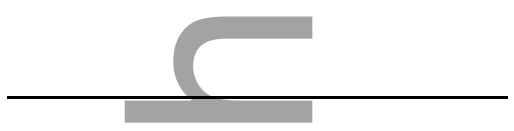

\footnotetext{
${ }^{65}$ K. MacDonald, One Red Paperclip: Or How an Ordinary Man Achieved His Dream with the Help of a Simple Office Supply (Three Rivers Press, 1st ed, 2007).

${ }^{66}$ Jones v Trustee of FC Jones \& Sons [1997] Ch 159.

67 ibid, 171 per Millett LJ.

${ }^{68}$ Foskett v McKeown n 1 above.
} 
asset must have the same market value as the asset used to acquire it'. ${ }^{69}$ Indeed, there is no reason to think that either right need have any exchange value at all.

If this is correct, and it seems difficult to avoid the conclusion that it is, we are no closer to solving our problem: if $\mathrm{T}$, a trustee, misappropriates a $£ 10$ note, title to which he holds on trust for B, buying with it a bottle of wine worth $£ 100$ (or 10p), how is it that value can be said to move from one right to the other in order to substantiate B's claim to title to the wine?

d) Wealth: abstracted exchange value

The sum of the immediate exchange value of an individual's assets, minus that individual's liabilities, produces a net amount that can be expressed as a money sum. This is often referred to as 'wealth', and it brings us to the second sense in which we might say that value 'moves' and can be traced through a transaction: if A has title to a scooter worth $£ 20$, and swaps it with $B$ for title to a bicycle worth $£ 10$, the cumulative exchange value of the assets in B's hands is greater than it was prior to the transaction, and the cumulative exchange value of the assets in A's is less, so that $£ 10$ can be said to have 'moved' from A to B.

If this is what we mean when we say that we trace value, there is no particular reason to tie it to the notion of an exchange of particular things or rights at all. After all, 'value may be received (and, more importantly, retained) by the defendant in a manner causally linked to the claimant without any transactional link between them'.70 Accordingly, Evans argues that we ought to free parties seeking to trace from the obligation of proving a transactional link. ${ }^{71}$

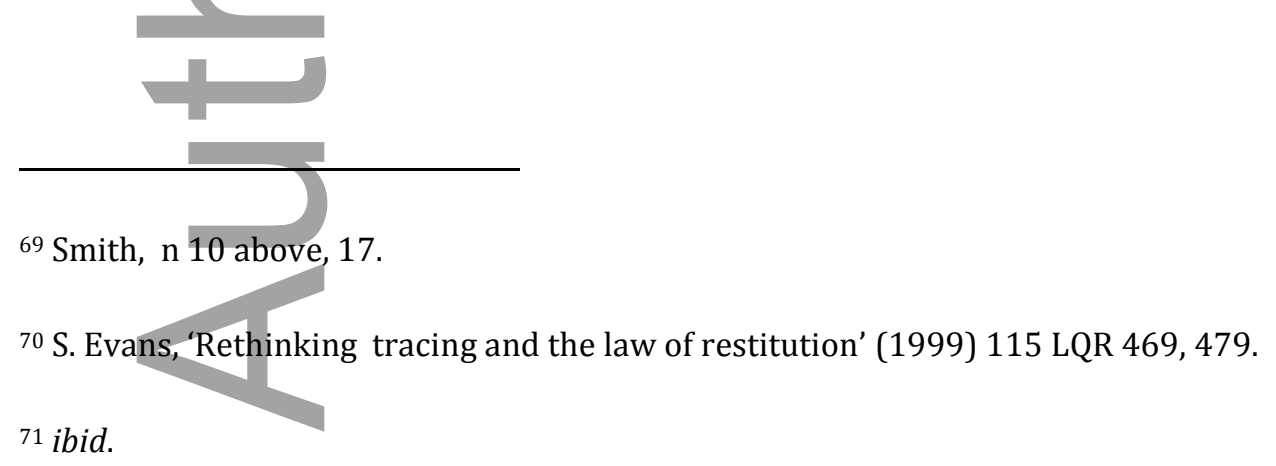

This article is protected by copyright. All rights reserved. 
This point is a good one. We cannot have it both ways: when we say that we 'trace value' we are either interested in (i) a transfer of value between individuals, in which case there is no obvious reason to insist upon the presence of an exchange of rights; or (ii) the exchange of particular rights, in which case there is no obvious reason to insist upon a transfer of wealth between individuals.

It is abundantly clear, however, that Evans' solution is not that which has been adopted by our authorities. In OJSC OIL Co Yugraneft v Abramovich, OJSC Oil Company Yugraneft (Yugraneft), which had a participation interest in LLC Oil Company SibneftYugra (Sibneft-Yugra), claimed to have been the victim of a massive fraud perpetrated by Mr Abramovich, and sought to trace into the proceeds of sale of Sibneft to Gazprom on the basis that a part of the (increased) value of the shares in Sibneft represented the (decreased) value of its interest in Sibneft-Yugra. ${ }^{72}$ The judge held that it could not, saying, 'At best there is a causal connection between the transfer and the increased value ... when what is required is a transactional link by which a new asset is exchanged for, and acquired with, the old one'. ${ }^{73}$ So, although Abramovich was better off as a result of the breach of trust (and Yugraneft was worse off), his rights as a shareholder in Sibneft were not exchanged for Yugraneft's participation interests, which still existed at the time of the claim. ${ }^{74}$

By contrast, if the claimant can demonstrate that some right in the defendant's hands is the exchange product of a right originally held by or for the claimant, it is neither here nor there that the transaction has made no difference to the defendant's wealth. In Foskett the defendants argued that the claimant could not trace from the premiums paid to the policy payout because,

\footnotetext{
${ }^{72}$ OJSC OIL Co Yugraneft v Abramovich n 16 above.

73 ibid at [365].

74 ibid.
} 
Those premiums were not made in exchange for anything since they did not increase the value of the policy or policy moneys. The same sum would have been paid out on M's death whether or not those premiums had been paid. ${ }^{75}$

Lord Millett dealt with that point swiftly:

[T] he question is one of attribution not causation. The question is not whether the same death benefit would have been payable if the last premium or last few premiums had not been paid. It is whether the death benefit is attributable to all the premiums or only to some of them. The answer is that death benefit is attributable to all of them because it represents the proceeds of realising the policy, and the policy in turn represents the product of all the premiums. ${ }^{76}$

That leaves (ii): when we 'trace value' we are not seeking to connect two different people by reference to a transfer of wealth, but two different rights. If A swaps title to a scooter for title to a bicycle, that B is better off as a result of the transaction is irrelevant: tracing simply connects A's prior title to the scooter with A's new title to the bicycle, and B's prior title to the bicycle with B's new title to the scooter, which it does on the basis of the exchange, not on the basis of the effect on the net worth of either A or B.

\section{e) Exchange potential}

One of the things that the holder of an assignable right can do is exchange it and by doing so obtain something in return. This does not tell us what he will receive in return: that must be determined by reference to the supply and demand of a particular market, in comparison with other assets within it. This will produce the 'exchange value' of that right. So, 'exchange potential' expresses the idea that 'I can exchange this right', whilst 'exchange value' expresses the idea that 'if I do I will be likely to receive $x$ '. Exchange

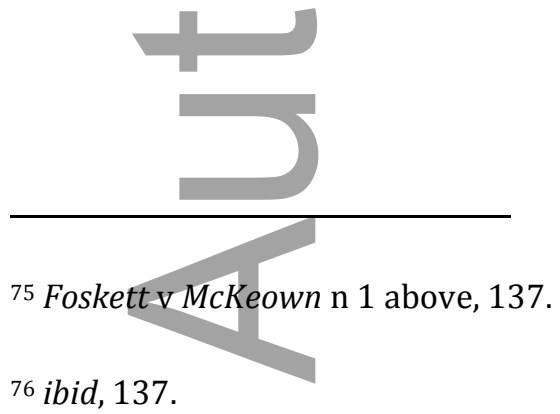

This article is protected by copyright. All rights reserved. 
value is subject to constant change. ${ }^{77}$ Exchange potential is not: ${ }^{78}$ even onerous assignable rights have exchange potential.

Control over the exchange potential of a thing is one of the incidents of title to it. This is the idea articulated by Hegel's statement that 'as full owner of the thing, I am owner both of its value and of its use'. ${ }^{79}$ The 'ownership' of value is not, of course, ownership in the sense of 'best title'. Rather, it captures the idea that a person with best title to something is in the best position to exploit its exchange potential. Penner puts this clearly: 'the right regarding value which ownership gives us is the right to realise, to capture, the exchange value of our property. It is a right to act in a certain way, not a right to something that is somehow already there'. 80

This, finally, is what is meant by those who describe tracing as the process of following the path of value from one asset to another:

If a $£ 100$ banknote is used to buy a painting, then the value inherent in ownership of the banknote is traceable into ownership of the painting. Ownership of the painting might be, or might become, worth $£ 10$ or $£ 10,000$. This does not change the conclusion that this asset was acquired with the other; the seller transferred ownership of the painting in exchange for receiving ownership of the banknote. This is what is meant by the notion that it is value which is traced from the first asset into the second. ${ }^{81}$

So, if $\mathrm{T}$, a trustee, misappropriates a $£ 10$ note, title to which he holds on trust for $\mathrm{B}$, buying with it a bottle of wine worth $£ 100, B$ is thought to be entitled to claim the latter because its acquisition is referable to T's exploitation of the exchange potential inherent

77 Benedetti v Sawiris n 64 above at [105] per Lord Reed.

78 J. Penner, 'Value, Property and Unjust Enrichment' in R. Chambers, J. Penner and C. Mitchell (eds), Philosophical Foundations of the Law of Unjust Enrichment (Oxford: OUP, 2009) 309.

${ }^{79}$ G. W. F. Hegel, Elements of the Philosophy of Right (A. Wood (ed)) (Cambridge: CUP, 1991) s 63.

80 Penner, $n 78$ above, 309.

81 Smith, n 10 above, 16-17. 
in title to the note. Of course, the same explanation is applied, as it must be, outside the context of title, to cases involving personal rights, so that value-as-exchange-potential is not a feature of title, but of the capacity for exchange of any right, personal or proprietary. ${ }^{82}$ For Birks, therefore, the 'key question' for tracing is simply 'whether the value inherent in the one asset has in whole or in part been used to acquire the other'. ${ }^{83}$

Yet, because it is a description of what can be done with a right, exchange potential cannot actually 'move' from one right to another through a substitution any more than 'edible' can move from an apple to the person that eats it. The continuity assumed by tracing terminology simply does not exist. That language can only be understood to express - poorly - what we already know, which is that an actor has made an exchange of one right for another. The translation of value into exchange potential tells us nothing new; certainly, it tells us nothing about the way in which we might prove that such an exchange has indeed taken place.

In what follows it is argued that concepts of value are not only theoretically but also practically misleading; at the root of the difficulties that courts have faced in attempting to extrapolate from examples such as Example (i) to more complex cases is the failure to recognise that the process of establishing a transactional link is guided centrally by the intention of the transacting parties.

\section{TRANSACTIONS}

The language of 'transaction' and 'transactional link' is commonplace in tracing discourse. However, because we have insisted that the way in which we link two assets is by following a continuous stream of value from one to another, we have assumed both that this exercise can be conducted without reference to the parties' intentions, and that the proof of such a link must involve mapping each step by which a transaction is

82 R. Chambers, 'Tracing and Unjust Enrichment' in J. Neyer, M. McInnes and S. Pitel (eds), Understanding Unjust Enrichment (Oxford: OUP, 2004) 265; 278.

83 P. Birks, 'Overview: Tracing, Claiming and Defences' in Peter Birks (ed), Laundering and Tracing (Oxford: OUP, 1995) 289. 
executed. It follows that if we cannot produce such a list, or if producing such a list reveals a period of time in which there is no asset in existence, we cannot trace.

In what follows it is argued that this approach to the process of demonstrating a transactional link is incorrect. The existence and content of a transaction cannot be determined without reference to the intentions of the parties to it. And if those intentions reveal that multiple transactions are intended to operate together to achieve a particular outcome, the intermediate steps are ignored. This allows us to deal much more straightforwardly with instances of multiple payment instructions and periods of indebtedness

f) Transactions and intention

Although we use the term 'transaction' often, it is not easily defined without reference to a particular context. The etymology of the term does not help us to narrow its conceptual limits. Transaction comes from the Latin 'transigere'. 'Trans' means 'across or through' and 'agere', which also takes the form 'actus', means 'to do, drive, lead, or pass time'. ${ }^{4}$ The only idea that appears in each use of 'transaction' is, accordingly, that there is some element of bilaterality of action or effect. So, 'transactional analysis' is an approach to psychological theory that developed from a study of human interaction by reference to individual developmental history; in computer science, 'transaction processing' is the unification of a sequence of information exchange.

'Transaction' in law contains this element of reciprocity, although it is not reciprocity of action or intention, but of legal effect. It is, as a consequence, broader than contract, which is our paradigm bilateral transaction: a gift is a transaction. If A gives $\mathrm{B}$ a bicycle there is an act - the physical movement by A of the bicycle - but there is also a 'transaction', because that act is both intended to and does change both parties' positions in law. Importantly, that change in the parties' rights and obligations arises out of the intention to change them: a car crash is not a transaction, nor does it become ${ }^{84}$ Shorter Oxford English Dictionary on Historical Principles vol 2 (Oxford: OUP, 6th ed, 2007). 
one if the driver intends to bring about the crash. This is so because the liability that arises from the wrong does not depend on the intention to create it. ${ }^{85}$ So, a legal transaction is the performance of an act that is intended to and does in fact change the legal rights and obligations of two or more persons, precisely because that is what is intended.

g) Characterising transactions

The ordinary approach to the characterisation of transactions is to look to the transactors' intentions to determine the content and type of transaction that they have created, deduced from consideration of the transaction as a whole. If this intention reveals that the parties intended several steps to operate as one, overarching, transaction, the intermediate steps are typically ignored.

In In re George Inglefield a furnishing company went into liquidation. A large proportion of its business consisted of letting out furniture on hire-purchase agreements, which it financed by virtue of a number of agreements with a discount company. At first instance Eve J held that these agreements amounted to a charge upon the future instalments payable under the hire-purchase agreement, which was void for non-registration. The Court of Appeal reversed that decision, holding that the agreements were 'out-and-out' sales. Lord Hanworth MR explained that the appropriate approach to characterisation was to 'see what are the rights and obligations of the parties to be derived from the consideration of the whole agreement' in order 'ascertain the substance of the transaction' ${ }^{86}$

In Curtain Dream plc v Churchill Merchanting Ltd Curtain Dream plc agreed to sell fabric under a finance agreement to a finance company (CML) and to enter into a separate 'trading agreement' by which CML purported to resell the fabric to Curtain

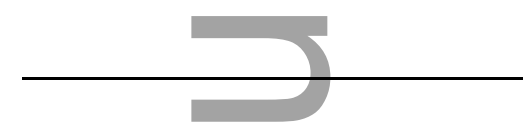

\footnotetext{
85 J. Hage, What is a Legal Transaction? at www.academia.edu/471098/What is a Legal Transaction (last accessed 14 April 2014).

${ }^{86}$ In Re George Inglefield Ltd [1933] Ch 1, 19 per Lord Hanworth MR.
} 
Dream plc, on terms reserving title in the fabric to CML. Knox J held that there was an 'indissoluble link between the various parts of the transaction', 87 so that it had to be regarded as a whole, and not as a series of independent transactions. ${ }^{88}$ Viewed in this way, its effect was to produce an 'exact degree of mutuality' with regard to the passing of the title, conclusively indicative of a mortgage or charge. 89

We take precisely the same approach in land law in order to determine whether the parties to a lease or licence have created the agreement indicated by the chosen label. In Antoniades v Villiers the landlord granted partners the right to occupy a small flat by separate but identical agreements, entered into contemporaneously. ${ }^{90}$ The agreements were expressed to be 'licenses' and expressly stated that exclusive possession was not granted, and that the use of the rooms was 'in common with the licensor and such other licensees or invitees as [he] may permit from time to time to use the said rooms'. The House of Lords unanimously held that the two agreements were interdependent and must be read together because,

There is an air of total unreality about these documents read as separate and individual licenses in the light of the circumstance that the appellants were together seeking a flat as a quasi-matrimonial home..$^{91}$

In tax law, individual transactions that appear to create a particular balance-sheet result, but which are designed to work as part of a network of transactions, will often be disregarded when the court determines the tax consequences of the wider transaction. In Ramsay v IRC the taxpayer company entered into a scheme known as the 'capital loss scheme' that was designed to create artificial capital losses on share transactions for the

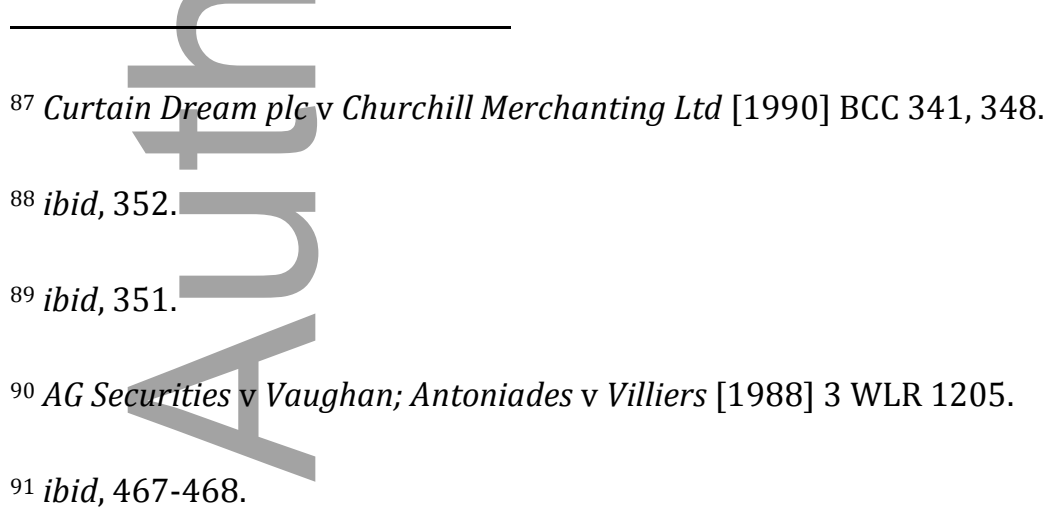

This article is protected by copyright. All rights reserved. 
sole purpose of reducing the amount of the capital gains tax payable. ${ }^{92}$ Lord Wilberforce said:

It is the task of the court to ascertain the legal nature of any transactions to which it is sought to attach a tax or a tax consequence and if that emerges from a series or a combination of transactions, intended to operate as such, it is that series or combination which may be regarded. ${ }^{93}$

Concluding that it would be 'quite wrong, and a faulty analysis, to pick out, and stop at, the one step in the combination which produced the loss, that being entirely dependent upon, and merely, a reflection of the gain', 94 the House of Lords held that, viewed as a whole, the transaction produced neither gain nor loss.

So, in order to determine the existence, content and type of transaction the parties have created, the court will have reference to their intention, deduced from the agreement as a whole. If this intention, so deduced, reveals that several transactions are interdependent, the intermediate steps will be ignored in determining their overall effect.

h) Tracing

The orthodox treatment of transactions in tracing bears little resemblance to the process just described. We saw above that the Court of Appeal in Relfo v Varsani adopted the position that, independent of intention, it could and must be demonstrated by evidence or inference 'that there is a direct chain of substitutions whereby the claimant's property was exchanged for another asset'. ${ }^{95}$ In other words, in the same way that we might show that a particular $£ 10$ note has made its way from A to B via an

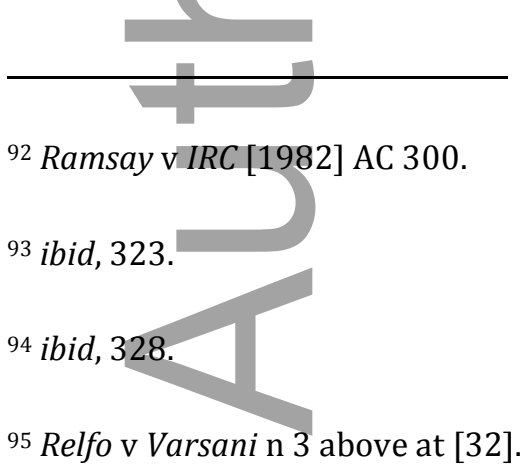


intermediary, ${ }^{96}$ in order to trace we must demonstrate that value once located within a particular account has moved from its first repository to another, and so on down the chain of substitutions. ${ }^{97}$ In that case factors contributing to such proof included 'the prior dealings between Mr Gorecia and the Varsani family, the prior dealings between Mr Gorecia and Ukrainian businessmen and between Mirren and Intertrade and the transactions between their accounts'. ${ }^{98}$

In the first part of this article I argued that references to the movement of value are an unhelpful way of expressing the process of identifying the product of a rights exchange. Here I show that it is always the executed intention of the parties that governs identification of a transactional link - rights exchange or otherwise - and that recognising this allows us to overcome the obstacles apparently created by instances of multiple intermediate accounts, clearing and credit.

In order to explain the process of tracing through bank transfers by reference to concepts of value, Smith uses the label 'tracing in transit', which he exemplifies as follows:

Example ( $\mathrm{x}$ ): A has a llama and he wants to give $\mathrm{B}$ a cow. $\mathrm{C}$ has a cow and wants a llama. So, A agrees with $\mathrm{C}$ that $\mathrm{A}$ will give the llama to $\mathrm{C}$ and $\mathrm{C}$ will give the cow to B.

Smith's analysis is this: 'A's bargain with $\mathrm{C}$ is that $\mathrm{A}$ will give the llama to $\mathrm{C}$, and in exchange $C$ will give the cow to $B$. Thus, A never sees the cow; he gives the llama to $\mathrm{C}$, who gives the cow to $\mathrm{B}^{\prime} .{ }^{99}$ He continues, 'if we were concerned with the value inherent in ownership of the llama, we could trace it through the substitution into the cow, and
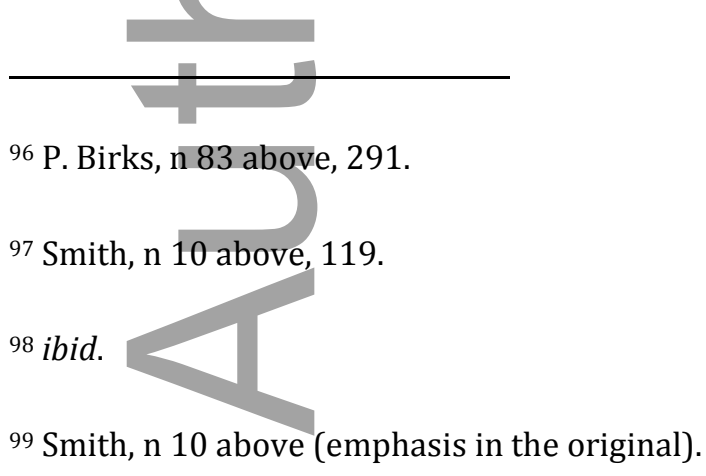
then follow the cow to $\mathrm{B}^{\prime} .^{100}$ Smith extrapolates from this example to that of a bank transfer:

Example (xi): A instructs his bank, C, to transfer $£ 400$ to $\mathrm{B}$.

Here, "The reason that the money received by B is traceably the money paid by A [is that] A 'bought' a payment from C; and this payment is the traceable proceeds of the value used to buy it'. 101

Yet, in neither example is it possible to prove, without reference to the intention of the parties, that the transactional product of A's right is in B's hands. In the first example, the reason that we know that title to the cow is connected to title to the llama - prior to or after its physical movement from C to B - is that A and C agreed that B should receive the former in return for C's acquisition of the latter. If, like Smith, we attempt to reconfigure the facts as an example of tracing plus tracking the movement of a physical asset - the cow - from A to B, we are simply using principles of following to express what we already know, which is that the right that B acquires to the cow is the transactional product of the right to the llama that A gave up.

In Example (xi) the pretence that we are simply following an asset from A's hands to B's instantly collapses. A bank payment involves at its most basic the execution of a payment instruction to debit one account and credit another. In such a case, nothing moves from A to B. Rather:

When a sum of money leaves A's account his chose in action quoad that sum is extinguished. When an equivalent sum is transferred to B's account there is created in B a fresh chose in action being the right to demand payment of that sum from his bank. ${ }^{102}$

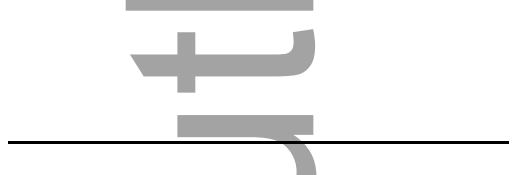

100 ibid (emphasis added).

101 ibid, 252.

$102 R$ v Preddy n 14 above. 
So, the most that we can say about the effect of the payment instruction in Example (xi) is that A loses a claim and B acquires one. B's right is a new right, to which A never had a claim. The way in which we connect that new right to A's prior claim is by reference to the payment instruction - accepted and acted upon by the bank - by which A's intention is revealed.

The same approach is apposite irrespective of the complexity of the facts. If several steps are designed to bring about a single payment, it is that overall payment that forms the heart of the transactional link between A and B. For the purposes of establishing a transactional link between the accounts, the following example is thus identical to Example (xi):

Example (V): A instructs Bank A to pay B, which Bank A does by instructing Bank B to credit B's account.

It is for this reason that the interposition of clearing is no problem at all for tracing: in order to establish a transactional link in any case involving a bank payment, the claimant must show that the parties involved in the transaction intended to, and did in fact, bring about a debit to the account held by or for the claimant, and that into which the claimant seeks to trace. The precise mechanisms by which inter-bank payment instructions are executed by the participating banks have no bearing on the execution of this process.

We are now able to see the fallacy in approaches to the following examples:

Example (iii): A transfers $£ 1000$ to C’s account, from which C pays B $£ 1000$.

Example (iv): A transfers $£ 1000$ to C's account. As a result, C pays B $£ 1000$ from a different account.

The orthodox conclusion is that A can establish a transactional link between his account and that of B in Example (iii) but not in Example (iv). In fact, whether this is so depends entirely upon whether A can establish that the transaction was designed to bring about a debit to his account and a credit to B's account - a payment, through an intermediary, 
from A to B. That the same account was used to execute each step in Example (iii) might be evidence pointing towards such a conclusion, but it is not itself conclusive; by contrast, the fact that a different account was employed in Example (iv) is neither here nor there, if it is manifest that the intermediate step was simply the mechanism for payment from A's account to B's.

The same will be true where the intermediate account is overdrawn:

Example (vii): A transfers $£ 1000$ from his account to C's account, which is overdrawn. $C$ uses that account to transfer $£ 1000$ to B’s account.

Here, any problem that might lie in connecting A's account to B's goes, not to establishing a continuous stream of value, but rather to intention. The proof of a transactional link in Examples (iii), (iv) or (vii) requires the claimant to demonstrate that the second transfer is not merely a consequence of the first, but rather occurs - as in Relfo v Varsani - as part of some overall design.

It remains only to deal with those cases which have typically been thought to engage the process known as 'backward tracing':

Example (ix): B buys a bicycle from $\mathrm{C}$ for $£ 10$ on credit. B steals a $£ 10$ note from $\mathrm{A}$ and uses it to meet the debt.

According to Conaglen regarding a right bought with a debt that is later repaid with the claimant's right as the product of that right 'ignores the legal mechanism' by which the asset was acquired. ${ }^{103}$ But it ought by now to be clear that ignoring the legal mechanism is precisely the process in which the courts, in characterising a particular transaction, ought to be engaged. The question is always: is there a single transaction uniting the right claimed and some right formerly held by or for the claimant? The interposition of credit, if it forms part of the mechanism for acquisition, does not preclude a positive response.

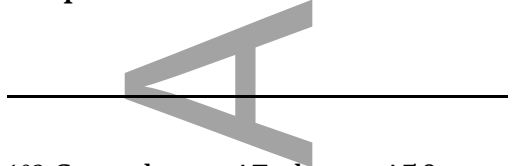

103 Conaglen, n 47 above, 450.

This article is protected by copyright. All rights reserved. 
Although it is by no means the dominant model, some evidence of this approach can be detected in the decided cases. In Agricultural Credit Corp of Saskatchewan v Pettyjohn (Pettyjohn) the claimant agreed to loan the defendants money to buy cattle.104 The defendants bought the cattle before the loan was made, using an overdraft facility, which the defendants later repaid with funds advanced by the claimant. The Saskatchewan Court of Appeal held that that made no difference to the establishment of a 'close and substantial connection' between the claimant's funds and title to the cattle, 105 considering that:

The appropriate principle of tracing in such a case is that where a set of chattels is replaced by another of like function in the affairs of the debtor, it shall be open to the court to find that the proceeds from the first were used to acquire the second, whatever the formalities of the transactions in question. ${ }^{106}$

The Privy Council recently reinforced this approach in Brazil v Durant, holding that where the parties anticipate that some onward payment will be reimbursed from funds misappropriated from the claimant, the interposition of credit does not prevent the claimant from establishing a transactional link. Of the decision in Pettyjohn, Lord Toulson said that the court was right 'not to divide minutely the connected steps by which, on any sensible commercial view, the purchase of the cattle was financed by the credit corporation, but to look at the transaction overall.' His Lordship continued:

The development of increasingly sophisticated and elaborate methods of money laundering, often involving a web of credits and debits between intermediaries, makes it particularly important that a court should not allow a camouflage of interconnected transactions to obscure its vision of their true overall purpose and effect. ${ }^{107}$

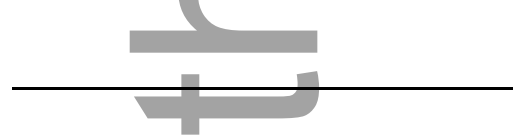

104 Agricultural Credit Corp of Saskatchewan v Pettyjohn 1991 CarswellSask 172.

105 ibid, 60

106 Pettyjohn ibid (emphasis added).

${ }^{107}$ Brazil v Durant $\mathrm{n} 19$ above at [37].

This article is protected by copyright. All rights reserved. 
The treatment of transactions advocated here provides a sound conceptual foundation for this statement: in our Example (ix) A must demonstrate that the 'true overall purpose and effect' of the transaction was to bring about the acquisition of title to the bicycle in exchange for title to the note.

We are now in a position to return, in sum, to the case with which this section began; in Relfo v Varsani the Court of Appeal was required, not to identify a continuous stream of value providing some non-normative connection between the accounts, but simply to show that the parties' intentions were to bring about the result which obtained, that funds were debited from Relfo's account and credited to Varsani's. Evidence of prior dealings contributed to the likelihood that the series of transactions was indeed intended to operate together to bring about that result. The inference drawn in a case such as Relfo v Varsani thus goes directly to the intention of the transacting parties. However the transaction is executed, the tracing question is: is the relevant change in legal relations sought and manifested as part of a single scheme?

Transactions and Claiming

None of what has been said thus far alters the conclusion that the proof of a particular kind of connection between two people or two rights does not provide a complete explanation for a particular claim. Nevertheless, value metaphors at once complicate the process of demonstrating that a single transaction links two rights, and obfuscate distinctions of normative importance. The purpose of what remains of this article is to demonstrate that several important questions are revealed only when the language of tracing is stripped away.

Importantly, tracking the path of value from one right to another makes the following two examples appear, for the purposes of establishing a link between the relevant rights, indistinguishable from one another:

Example (ii): T holds a bank account on trust for B. He transfers $£ 1000$ from the trust account to C's account. 
Example (xii): D, a director of P Co, transfers $£ 1000$ from P Co's account to C's account.

Explained through the tracing paradigm, in each example the claimant seeks to demonstrate that 'his' value, originally located in the account held by (Example (xii)) or for (Example (ii)) him is now located in C's right, in order to transmit his claim from one right to the other.

Without concepts of value and tracing, however, it becomes clear that the examples are not the same: in the first, the parties to the transaction are $\mathrm{T}$ and $\mathrm{C}$; in the second, since D acts as agent for P Co, they are P Co and C. This has important ramifications for the justification of any subsequent claim: an action to undo the effects of a transaction - however complex - to which the claimant was a party is not normatively identical to an action in respect of a transaction entered into by a person who has neither the intention nor capacity to change the claimant's position with respect to some third party. Such distinctions must inform any explanation for the various remedies that are currently thought to stem in some sense from the transmission of claims from rights to their traceable products.

Only now, with this in mind, is it possible to return to the example with which this article began:

Example (i): T holds title to a $£ 10$ note on trust for B. T uses that note to purchase a bottle of wine. He does not have B's authority to do so.

We have already seen that this example has typically attracted the same explanation as that applied to Examples (xii) and (ii): B traces the value of his original claim into T's new right. We have also seen that there are irreparable problems with this account, so that we have not yet answered the question that framed our discussion of value: why is it that B can assert a claim to the title to the bottle of wine?

A robust answer to that question requires a great deal of independent analysis, which cannot be conducted here. It suffices to conclude simply with the observations that: (i) without the language of value and tracing, the substitution by a trustee of a right 
held on trust for the claimant no longer looks theoretically interchangeable with the execution of a payment instruction by which some third party account is credited; and (ii) since nothing now supports the assumption that an exchange by a fiduciary who owes custodial responsibilities to the claimant must be treated in the same way as a simple theft and substitution (Example (ix)), it becomes necessary to identify whether and if so how the status of T's initial relationship with B drives or affects the claim that arises on the facts of either Example (i) or Example (ii).

\section{CONCLUSION}

It should now be clear that the idea of 'tracing value' not only fails to tells us anything that we do not already know about the process of identifying a transactional link, but actively misleads courts attempting to execute that process. The content of a transaction cannot be determined without reference to the intention of the parties, deduced from the agreement as a whole. If this process reveals that the parties intended several steps to work together, we look not at the precise mechanisms by which a change in legal relations is sought, but rather at its overall effect.

Recognising that nothing in fact flows through the stages of a payment, sale or other transaction is important not only for the analytical question - 'what is tracing?' but also in identifying the justification for a particular claim. Rather than looking to value as a vessel for claims, instead we must identify the normative effect of the proof of a transactional link, rights exchange or otherwise. This is no small task, but removing the metaphorical premises of tracing ought to provoke more fruitful discussions concerning the explanation for personal and proprietary claims against fiduciaries, fraudsters and those who transact with them.

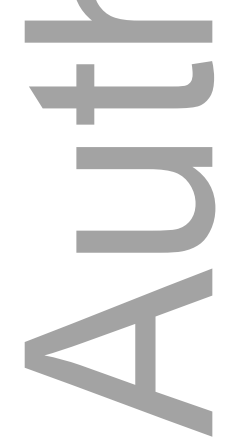




\section{University Library}

\section{- M M N E R VA A gateway to Melbourne's research publications}

Minerva Access is the Institutional Repository of The University of Melbourne

Author/s:

Cutts, $T$

Title:

Tracing, Value and Transactions

Date:

2016-05-01

Citation:

Cutts, T. (2016). Tracing, Value and Transactions. MODERN LAW REVIEW, 79 (3), pp.381-405. https://doi.org/10.1111/1468-2230.12189.

Persistent Link:

http://hdl.handle.net/11343/291210 